Article

\title{
Broadening the Biocatalytic Toolbox-Screening and Expression of New Unspecific Peroxygenases
}

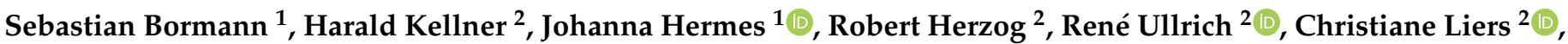 \\ Roland Ulber $^{3}$, Martin Hofrichter ${ }^{2}$ (D) and Dirk Holtmann 1,4,5,* \\ 1 Industrial Biotechnology, DECHEMA Research Institute, Theodor-Heuss-Allee 25, 60486 Frankfurt am Main, \\ Germany; sb.bormann@googlemail.com (S.B.); hermes_johanna@web.de (J.H.) \\ 2 International Institute Zittau, Technical University of Dresden, Markt 23, 02763 Zittau, Germany; \\ harald.kellner@tu-dresden.de (H.K.); robert.herzog1@tu-dresden.de (R.H.); rene.ullrich@tu-dresden.de (R.U.); \\ christiane.liers@tu-dresden.de (C.L.); martin.hofrichter@tu-dresden.de (M.H.) \\ 3 Institute of Bioprocess Engineering, University of Kaiserslautern, Gottlieb-Daimler-Strasse 49, \\ 67663 Kaiserslautern, Germany; ulber@mv.uni-kl.de \\ 4 Institute of Bioprocess Engineering and Pharmaceutical Technology, Technische Hochschule Mittelhessen, \\ Wiesenstraße 14, 35390 Giessen, Germany \\ 5 Research Division Bioresources, Fraunhofer Institute for Molecular Biology and Applied Ecology (IME), \\ Ohlebergsweg 12, 35392 Giessen, Germany \\ * Correspondence: dirk.holtmann@lse.thm.de
}

\section{check for} updates

Citation: Bormann, S.; Kellner, H.; Hermes, J.; Herzog, R.; Ullrich, R.; Liers, C.; Ulber, R.; Hofrichter, M.; Holtmann, D. Broadening the Biocatalytic Toolbox-Screening and Expression of New Unspecific

Peroxygenases. Antioxidants 2022, 11, 223. https://doi.org/10.3390/ antiox 11020223

Academic Editors: Alessandra Napolitano and David Burritt

Received: 22 November 2021

Accepted: 17 January 2022

Published: 24 January 2022

Publisher's Note: MDPI stays neutral with regard to jurisdictional claims in published maps and institutional affiliations.

Copyright: (C) 2022 by the authors. Licensee MDPI, Basel, Switzerland. This article is an open access article distributed under the terms and conditions of the Creative Commons Attribution (CC BY) license (https:// creativecommons.org/licenses/by/ $4.0 /)$.
Abstract: Unspecific peroxygenases (UPOs) catalyze the selective transfer of single oxygen atoms from peroxides to a broad range of substrates such as un-activated hydrocarbons. Since specific oxyfunctionalizations are among the most-desired reactions in synthetic chemistry, UPOs are of high industrial interest. To broaden the number of available enzymes, computational and experimental methods were combined in this study. After a comparative alignment and homology modelling, the enzymes were expressed directly in P. pastoris. Out of ten initially selected sequences, three enzymes (one from Aspergillus niger and two from Candolleomyces aberdarensis) were actively expressed. Cultivation of respective expression clones in a bioreactor led to production titers of up to $300 \mathrm{mg} \mathrm{L}^{-1}$. Enzymes were purified to near homogeneity and characterized regarding their specific activities and $\mathrm{pH}$-optima for typical UPO substrates. This work demonstrated that directed evolution is not necessarily required to produce UPOs in P. pastoris at respective titers. The heterologous producibility of these three UPOs will expand the toolbox of available enzymes and help to advance their synthetic application.

Keywords: unspecific peroxygenases; EC 1.11.2.1; Pichia pastoris; direct expression

\section{Introduction}

Unspecific peroxygenases (UPOs; EC 1.11.2.1), members of the heme-thiolate proteins, catalyze the selective transfer of single oxygen atoms from peroxides $\left(\mathrm{H}_{2} \mathrm{O}_{2}, \mathrm{ROOH}\right)$ to diverse target molecules including un-activated hydrocarbons [1,2]. In general, hydrogen peroxide driven biocatalysis combines the high oxidation power of $\mathrm{H}_{2} \mathrm{O}_{2}$ and its environmentally friendly properties with the high selectivity and further advantages of enzymatic oxidation reactions [3]. UPOs are found with few exceptions (i.e., Peronosporomycetes) exclusively in true fungi (Eumycota). Although their exact physiological function is unknown, they have been widely studied regarding their application potential, since specific oxyfunctionalizations are among the most-desired reactions in synthetic chemistry [4]. The easiness and the wide range of reactions catalysed by peroxygenases make them promising catalysts for preparative oxy-functionalizations [5].

Nowadays, thousands of UPO sequences can be found in genome-sequenced fungi, but only a handful of wild-type enzymes and a few recombinantly expressed UPOs have been characterized and used in lab-scale studies. Examples are wild-type UPOs from 
Cyclocybe (Agrocybe) aegerita, Marasmius rotula, or Chaetomium globosum, recombinantly produced UPOs from Coprinopsis cinerea, Collariella (Chaetomium) virescens, Daldinia caldariorum, Hypoxylon sp. EC38, or evolved variants from Candolleomyces (Psathyrella) aberdarensis and Cyclocybe aegerita [6-9]. Chloroperoxidase (CPO; EC 1.11.1.) from the ascomycetous sooty mold Leptoxyphium (Caldariomyces) fumago forms an exception, since it phylogenetically belongs to the UPOs (but not according to its EC classification) and can be produced as a wild-type enzyme in larger amounts $\left(>500 \mathrm{mg} \mathrm{L}^{-1}\right)$.

One major bottleneck so far remains the lack of recombinant expression of a representative selection of UPO genes with satisfactory expression levels $\left(>100 \mathrm{mg} \mathrm{L}^{-1}\right)$. In particular, the common Escherichia coli expression system has not properly worked for many years and still does not when it comes to UPOs. Only recently has it become possible to produce small amounts of active UPOs using a modified E. coli expression system, although this did not work in the case of all UPO constructs tested and always occurred without glycosylation [7]. In comparison, yeast systems (Saccharomyces cerevisiae and Pichia pastoris (i.e., Komagataella phaffii) appear to be more promising for recombinant expression and specifically for enzyme evolution. Examples for the successful expression and evolution are the UPOs from Cyclocybe aegerita and Candolleomyces aberdarensis [9]. However, prior to the successful expression of appreciable rUPO titers in P. pastoris, these corresponding genes had to be evolved, particularly in the signal peptide and sometimes also in the core domain [6].

In this study, we took another approach by selecting candidates after comparative alignments and homology modelling, and then proceeding with their direct expression in P. pastoris, thereby bypassing the time-consuming step of enzyme evolution in S. cerevisiae. With this approach, we aimed to accelerate the search for functional active UPO enzymes, which could provide a suitable platform for subsequent manipulations. In total, we tested 10 synthetically prepared and codon-optimized UPO genes for recombinant expression. The putative UPO genes (Table 1) were identified based on sequence motives, and a subset of protein sequences was investigated in this work. The selection was biased towards "short" UPOs $(<30 \mathrm{kDa})$ as their expression in yeast has remained elusive, while the wellexpressible UPOs from the Cyclocybe (Agrocybe) aegerita variant PaDa-I (AaeUPO-PaDa-I) and Coprinopsis cinerea (rCciUPO) belong to the "long" UPO subset [10].

Table 1. Investigated UPOs for recombinant expression in P. pastoris.

\begin{tabular}{|c|c|c|}
\hline $\begin{array}{c}\text { Organism of Origin, Accession } \\
\text { Number }\end{array}$ & $\begin{array}{l}\text { Individual Enzyme } \\
\text { Designation }\end{array}$ & $\begin{array}{l}\text { Calculated MW kDa w/wo } \\
\text { Signal Peptide }\end{array}$ \\
\hline Aspergillus niger XP_025450509 & rAniUPO & $29.4 / 27.6$ \\
\hline Aspergillus versicolor OJJ01936 & AveUPO & $28.4 / 26.7$ \\
\hline Chaetomium globosum XP_001219540 & CglUPO & $29.3 / 27.6$ \\
\hline Kretzschmaria deusta ARH52644 & KdeUPO & $27.8 / 26.2$ \\
\hline Marasmius fiardii KAF9260270 & MfiUPO & $28.2 / 26.2$ \\
\hline Mycena galopus Mycgal1 I 2083377* & MgaUPO & $28.6 / 26.4$ \\
\hline $\begin{array}{c}\text { Candolleomyces aberdarensis } \\
\text { RXW18363 }\end{array}$ & CabUPO1 & $41.3 / 38.8$ \\
\hline $\begin{array}{c}\text { Candolleomyces aberdarensis } \\
\text { RXW17618 }\end{array}$ & CabUPO2 & $41.9 / 39.3$ \\
\hline $\begin{array}{l}\text { Trichoderma harzianum } \\
\text { XP_024770464 }\end{array}$ & ThaUPO1 & $33 / 31.1$ \\
\hline Trichoderma harzianum KKO99714 & ThaUPO2 & $28.6 / 26.7$ \\
\hline
\end{tabular}




\section{Material and Methods}

\subsection{UPO Candidate Selection}

The overall selection followed an UPO database and alignments including more than 2000 protein sequences used in Hofrichter et al. [1]. Especially sequences larger than 500 amino acids and shorter than 200 amino acids as well as partial sequences were excluded. Sequences with problems derived from wrong intron-exon boundaries of the predicted genes during genome sequencing projects were removed, as well as sequences with missing core motifs like the PCP and EHD-S/EGD-S motifs distal and proximal of the heme center [1]. Then, 10 candidates displaying the diverse taxonomical and biochemical nature of UPOs (i.e., short and long UPOs from Ascomycota and Basidiomycota) were selected after tertiary structure modelling using I-TASSER [11] or C-I-TASSER [12] and visualization in PyMOL 2 (Schrödinger, New York, NY, USA). Thereby, especially the variable substrate channel architecture was in the focus for selection. For docking simulations of the substrate veratryl alcohol, the PyMOL plugin NRGSuite (version 2.48I, Dr. Rafael Najmanovich in Université de Sherbrooke, Sherbrooke, Quebec, Canada) was used [13]; a small phylogeny of the selected candidates and important UPO references was calculated using maximum likelihood (PhyML 3, substitution model: LG + I + G, [14] implemented in Geneious Prime 2020 [15]). Signal peptide prediction was carried out using SignalP 5 [16].

\subsection{Chemicals, Strains and Plasmids}

Chemicals were purchased from either Sigma-Aldrich (Schnelldorf, Germany), CarlRoth (Karlsruhe, Germany), or VWR (Darmstadt, Germany) in $>97 \%$ purity. Pichia pastoris X33 and zeocin were purchased from ThermoFisher (Dreieich, Germany). Competent Escherichia coli NEB 5-alpha cells were purchased from New England Biolabs (NEB, Frankfurt, Germany). Expression plasmid pPpB1 was provided by the group of Anton Glieder (Technical university Graz, Graz, Austria).

\subsection{Preparation and Transformation of Expression Plasmids}

Genes of putative UPO genes were synthesized by BioCat (Heidelberg, Germany) in pUC19. Coding sequences (CDSs) are given in the Supplementary Information (SI). Genes and the plasmid backbone pPpB1 were amplified by polymerase chain reaction (PCR) using Q5 polymerase (NEB) with the following protocol: initial denaturation at $98^{\circ} \mathrm{C}$ for $30 \mathrm{~s}$, followed by 30 cycles with $10 \mathrm{~s}$ at $98^{\circ} \mathrm{C}, 15 \mathrm{~s}$ at primer melting temperature $\left(\mathrm{T}_{M}\right.$, SI Table S1, $30 \mathrm{~s} \mathrm{~kb}^{-1}$ at $72{ }^{\circ} \mathrm{C}$, and a final extension at $72{ }^{\circ} \mathrm{C}$ for $120 \mathrm{~s}$. PCR products were cleaned up using the DNA clean and concentrator-5 kit (Zymo Research, Freiburg, Germany). Amplified genes and plasmid backbone were mixed in 3:1 molar ratio, digested by DpnI (NEB), ligated without further purification using isothermal assembly [17], and transformed into E. coli NEB 5-alpha according to the manufacturer's protocol for heat shock transformation. E. coli NEB 5-alpha colonies were selected on low-salt LB $\left(10 \mathrm{~g} \mathrm{~L}^{-1}\right.$ tryptone, $5 \mathrm{~g} \mathrm{~L}^{-1}$ yeast extract, $\left.5 \mathrm{~g} \mathrm{~L}^{-1} \mathrm{NaCl}\right)$ agar $\left(15 \mathrm{~g} \mathrm{~L}^{-1}\right)$ containing $25 \mathrm{mg} \mathrm{L}^{-1}$ zeocin. Plasmids were purified from cultures after overnight cultivation in low-salt LB + zeocin at $37^{\circ} \mathrm{C}$ and $180 \mathrm{rpm}$ using the GeneJET Plasmid MiniPrep Kit (ThermoFisher, Dreieich, Germany). Sequences of the cloned UPO-genes were verified by Sanger sequencing (Eurofins, Hamburg, Germany). Plasmids were linearized by digestion with PmeI and cleaned up (vide supra). Competent P. pastoris X33 cells were prepared as follows: $500 \mathrm{~mL}$ of YPD.media $\left(10 \mathrm{~g} \mathrm{~L}^{-1}\right.$ yeast extract, $20 \mathrm{~g} \mathrm{~L}^{-1}$ peptone, $20 \mathrm{~g} \mathrm{~L}^{-1}$ glucose) was incubated inoculated from an overnight culture and grown overnight to an optical density determined at $600 \mathrm{~nm}\left(\mathrm{OD}_{600}\right)$ of 1-1.5. Cells were pelleted at $1500 \mathrm{~g}$, washed twice with $250 \mathrm{~mL}$ ice-cold water, washed once with $20 \mathrm{~mL}$ ice-cold $1 \mathrm{M}$ sorbitol, and finally resuspended in $1 \mathrm{~mL} 1 \mathrm{M}$ sorbitol. Linearized plasmid (4-8 $\mu \mathrm{g})$ and $80 \mu \mathrm{L}$ competent cells were mixed in a pre-cooled $2 \mathrm{~mm}$ electroporation cuvette and incubated for $5 \mathrm{~min}$. Electroporation was carried out using a Gene Pulser Xcell (Bio-Rad, Dreieich, Germany) with settings for Saccharomyces cerevisiae. Immediately after electroporation, $1 \mathrm{M}$ sorbitol was added and cells were transferred to $1.5 \mathrm{~mL}$ reaction vials and incubated at $30{ }^{\circ} \mathrm{C}$ for about $60 \mathrm{~min}$, after which an equal volume of YPD was 
added and incubation was continued for 30-60 min. Aliquots were spread onto YPD agar containing $1 \mathrm{M}$ sorbitol and $100 \mathrm{mg} \mathrm{L}^{-1}$ zeocin and incubated at $30{ }^{\circ} \mathrm{C}$ for several days until colonies were visible.

\subsection{Screening of P. pastoris Clones for UPO Activity}

P. pastoris X33 colonies (24 colonies for each UPO-expression plasmids) from zeocin selection plates were picked into 96 deep-well plates (DWPs) and cultivated at $30{ }^{\circ} \mathrm{C}$, $800 \mathrm{rpm},>80 \%$ humidity in a Microtron (InforsHT) according to the screening strategy described by [18] with the following changes. The initial addition of methanol-containing medium was carried out when glucose was depleted as determined by sampling of several wells using a Reflecoquant ${ }^{\circledR}$ (Merck, Darmstadt, Germany) system. Following the initial methanol-addition, additional methanol was fed every 17-24 h. Samples for activity determination $(50 \mu \mathrm{L})$ were taken before feeding of methanol. Cultivation was terminated after about $100 \mathrm{~h}$. Enzyme activity in the culture supernatant was determined using the 2,2'-Azino-bis(3-ethylbenzthiazoline-6-sulfonic acid) diammonium salt (ABTS) and 5-Nitro-1,3-benzodioxole (NBD) assays (vide infra) [19].

\subsection{Expression of Recombinant Protein}

In order to produce the proteins, those P. pastoris X33 clones that exhibited UPO activity in the screening were cultivated in a 1-L (working volume) $4 \times$ DASGIP parallel bioreactor system (Eppendorf). Cultivations were carried out as described by Cino et al. 1999 [20] with the following adaptions. Reactors were inoculated to an $\mathrm{OD}_{600}$ of 1-2 at an initial cultivation volume of $500 \mathrm{~mL}$ (50\% working volume). Glycerol and methanol feed rates during the respective fed-batch phases were based on the dissolved oxygen (DO) concentration which had a set-point of $30 \%$ and was controlled by stirring rate ( $\leq 1200 \mathrm{rpm})$, aeration rate ( $\left.\leq 50 \mathrm{~L} \mathrm{~min}^{-1}\right)$, and oxygen content $(21-100 \%) ; \mathrm{pH}$ was held above 5 by the addition of $15 \%$ ammonia. Temperature was set at $30{ }^{\circ} \mathrm{C}$. DO-based feeding rates for glycerol were 0-20\% DO, 2-4 mL h ${ }^{-1}, 20-30 \% \mathrm{DO}, 4-8 \mathrm{~mL} \mathrm{~h}^{-1}, 30-50 \% \mathrm{DO}, 8-10 \mathrm{~mL} \mathrm{~h}^{-1}$, $>50 \% \mathrm{DO}$, and $10 \mathrm{~mL} \mathrm{~h}^{-1}$. For methanol, the profile was: $0-25 \% \mathrm{DO}, 0-3 \mathrm{~mL} \mathrm{~h}^{-1}, 25-30 \%$ DO, 3-4 mL h ${ }^{-1}, 30-40 \% \mathrm{DO}, 4-6 \mathrm{~mL} \mathrm{~h}^{-1}$, >40\% DO, and $6 \mathrm{~mL} \mathrm{~h}^{-1}$.

\subsection{Protein Purification}

Culture broth was removed from bioreactors and initially clarified by centrifugation at $15,000 \times g$. Further clarification was carried out by crossflow-filtration using a $0.2 \mu \mathrm{m}$ membrane cassette (Vivaflow $2000.2 \mu \mathrm{m}$ PES, Sartorius, Göttingen, Germany). High-molecular weight compounds were concentrated using a $10 \mathrm{kDa}$ cut-off crossflow-ultrafiltration membrane module (Vivaflow 200, 10 kDa, PES, Sartorius, Göttingen, Germany) followed by a further concentration using ultrafiltration centrifugal concentrators (Vivaspin $20 \mathrm{~mL}, 3 \mathrm{kDa}$, Sartorius, Göttingen, Germany). Fast protein liquid chromatography (FPLC) was carried out using an Azura FPLC system (Knauer, Berlin, Germany). Concentrated samples were clarified using $0.2 \mu \mathrm{m}$ PES syringe filters (VWR, Darmstadt, Germany) and mixed with an equal volume of $10 \mathrm{mM}$ potassium phosphate buffer (KPi) pH 7 with $2 \mathrm{M}$ ammonium sulfate prior to hydrophobic interaction chromatography (HIC). HIC was carried out using a $250 \mathrm{~mL}$ (3.6 cm inner diameter) column packed with Toyopearl butyl $650 \mathrm{M}$ (Tosoh, Griesheim Germany). Samples were applied directly to the column at a flow-rate of $4 \mathrm{~mL}$ $\min ^{-1}$. Proteins were eluted using a binary gradient with buffers consisting of $10 \mathrm{mM}$ KPi pH 7 with $1 \mathrm{M}$ ammonium sulfate (buffer A) and without ammonium sulfate (buffer B) at a flow rate of $8 \mathrm{~mL} \mathrm{~min}{ }^{-1}$. The elution profile was 1 column volume (CV) buffer A followed by a linear gradient of $100 \%$ buffer A to $100 \%$ buffer B over $1.4 \mathrm{CV}$. Fractions with a

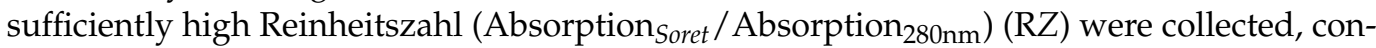
centrated, and dialyzed against size exclusion chromatography (SEC) buffer consisting of $10 \mathrm{mM} \mathrm{KPi} \mathrm{pH} 7$ with $150 \mathrm{mM} \mathrm{NaCl}$. SEC was carried out using a HiPrep 16/60 Sephacryl S-300 HR column $(1.6 \mathrm{~cm}$ inner diameter, $120 \mathrm{~mL} \mathrm{CV}$, GE Healthcare, Solingen, Germany). Samples were applied to the column using a sample loop $(1.1 \mathrm{~mL})$ at a flow-rate of 


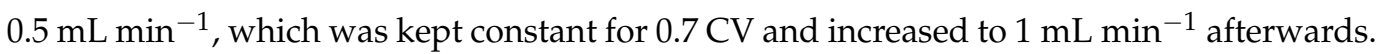
Samples with a sufficiently high RZ were collected, concentrated, and dialyzed against $100 \mathrm{mM} \mathrm{KPi} \mathrm{pH} 7$ for characterization experiments.

\subsection{Assays}

Enzyme activity assays were carried out using a UV-1700 (Shimadzu, Duisburg, Germany) in semi-micro poly(methyl methacrylate) (PMMA) cuvettes (pathlength $1 \mathrm{~cm}$ ) at room temperature. For screening of $P$. pastoris X33 clones, assays were carried out in 96-well flat bottom microtiter plates (MTPs) using an Infinite 200 Pro (Tecan, Crailsheim, Germany). Assay volume in MTPs was $0.2 \mathrm{~mL}$ with the same composition as given for assays carried out in semi-micro cuvettes.

Routine ABTS (2,2'-azino-bis(3-ethylbenzothiazoline-6-sulfonic acid) assay consisted of $750 \mu \mathrm{L} 100 \mathrm{mM} \mathrm{Na} 2 \mathrm{HPO}_{4} /$ citric acid buffer $\mathrm{pH}$ 4.4, $100 \mu \mathrm{L} 3 \mathrm{mM}$ ABTS, $50 \mu \mathrm{L}$ $40 \mathrm{mM} \mathrm{H}_{2} \mathrm{O}_{2}$, and $100 \mu \mathrm{L}$ sample. For the determination of pH-optima, $750 \mu \mathrm{L}$ Mcllvaine buffer $\left(200 \mathrm{mM} \mathrm{Na} \mathrm{HPO}_{4} / 100 \mathrm{mM}\right.$ citric acid) was used. Absorption was determined at $420 \mathrm{~nm}$; product concentration was calculated with an extinction coefficient of $36,000 \mathrm{M}^{-1} \mathrm{~cm}^{-1}$ [21].

The $\mathrm{pH}$ optima of unspecific peroxygenases (UPOs) for veratryl alcohol (VA) were determined with the following assay mixture: $840 \mu \mathrm{L}$ McIlvaine buffer, $100 \mu \mathrm{L} 50 \mathrm{mM}$ VA, $50 \mu \mathrm{L} 40 \mathrm{mM} \mathrm{H}_{2} \mathrm{O}_{2}$, and $10 \mu \mathrm{L}$ sample. Absorption was determined at $310 \mathrm{~nm}$; product concentration (veratraldehyde) was calculated with an extinction coefficient of $9300 \mathrm{M}^{-1} \mathrm{~cm}^{-1}$ [21].

The routine NBD assay (following demethylenation) consisted of $550 \mu \mathrm{L} 100 \mathrm{mM}$ $\mathrm{KP} i \mathrm{pH}$ 7, $100 \mu \mathrm{L} 5 \mathrm{mM}$ NBD (5-nitro-1,3-benzodioxole) in acetonitrile, $200 \mu \mathrm{L} \mathrm{H}_{2} \mathrm{O}$, $50 \mu \mathrm{L} 20 \mathrm{mM} \mathrm{H}_{2} \mathrm{O}_{2}$, and $100 \mu \mathrm{L}$ sample. pH optima of the UPOs for NBD were determined with the following assay composition: $750 \mu \mathrm{L}$ Mcllvaine buffer, $100 \mu \mathrm{L} 5 \mathrm{mM}$ NBD in acetonitrile, $50 \mu \mathrm{L} 20 \mathrm{mM} \mathrm{H}_{2} \mathrm{O}_{2}$, and $100 \mu \mathrm{L}$ sample. Absorption was determined at $425 \mathrm{~nm}$; product concentration (4-nitrocatechol) was calculated with an extinction coefficient of $9700 \mathrm{M}^{-1} \mathrm{~cm}^{-1}[19]$.

\subsection{Protein Characterization}

Protein concentrations were determined using the Bio-Rad Protein Assay Kit II (Bio-Rad, Dreieich, Germany) according to the manufacturer's protocol using a bovine serum albumin dilution series for calibration. Sodium dodecyl sulfate-polyacrylamide gel electrophoresis (SDS-PAGE) was carried out using Mini-PROTEAN TGX precast gels and Laemmli sample buffer (Bio-Rad, Dreieich, Germany) with $\beta$-mercaptoethanol as a reducing agent, according to the manufacturer's recommendations. Gels were stained with colloidal coomassie stain [22]. For glycosylation analysis, proteins were treated with PNGase F (NEB) according to the manufacturer-provided denaturing conditions protocol. Absorption spectra of purified proteins were determined on a NanoDrop 2000 (ThermoFisher, Dreieich, Germany).

\section{Results and Discussion}

\subsection{Selection of Genes}

Currently, several thousands of UPO genes are available in databases (NCBI, but also at JGI Mycocosm). As a first premise, we decided to select genes phylogenetically close to known and "working" reference UPOs, like those of the enzymes from Cyclocybe aegerita and Marasmius rotula (Figure 1). Secondly, the selected genes should include correct intron-exon boundaries (which was confirmed by extensive evaluation of alignments), a predicted signal peptide (e.g., using SignalP 5), and a substrate channel after homology modelling with different characteristics like more aliphatic or more aromatic amino acids (Figure 2). Phylogenetically, UPOs are highly diverse and include several (sub)families and clusters, like short and long UPOs as here and previously shown (Figure 1, [1]), and will provide plentiful candidates in future expression experiments. 


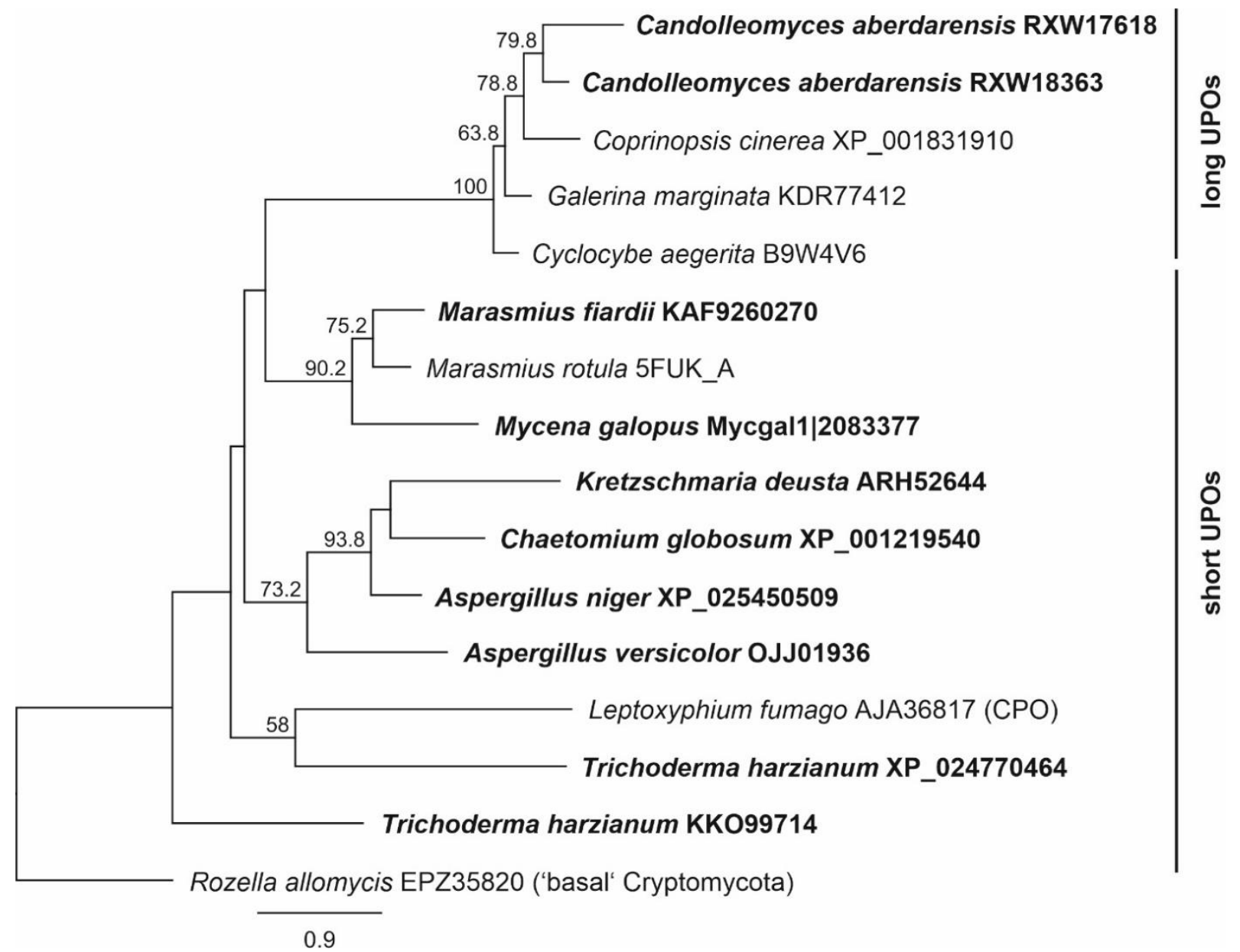

Figure 1. Maximum likelihood tree including unspecific peroxygenase (UPO) candidates for recombinant expression and references. Branch support was estimated by 500 bootstrap replicates.

\subsection{Expression of Putative UPO Genes in P. pastoris}

Putative UPO genes were cloned into the Pichia pastoris expression vector pPpB1 [23] under control of the methanol-inducible aox1-promoter, which has been successfully utilized to express AaeUPO-PaDa-I [24]. P. pastoris transformants were successfully generated for all 10 expression constructs. After transformation, 24 clones per construct were picked and cultivated in deep-well plates (DWPs) for $94 \mathrm{~h}$. Supernatant from clones was tested for UPO activity using the ABTS and NBD assays. Clones transformed with expression plasmids for two UPOs from Candolleomyces aberdarensis (CabUPO1 and CabUPO2) and UPO from Aspergillus niger (rAniUPO) exhibited activity with both assays, while no activity could be determined for either assay for all other constructs (Figure S1). 


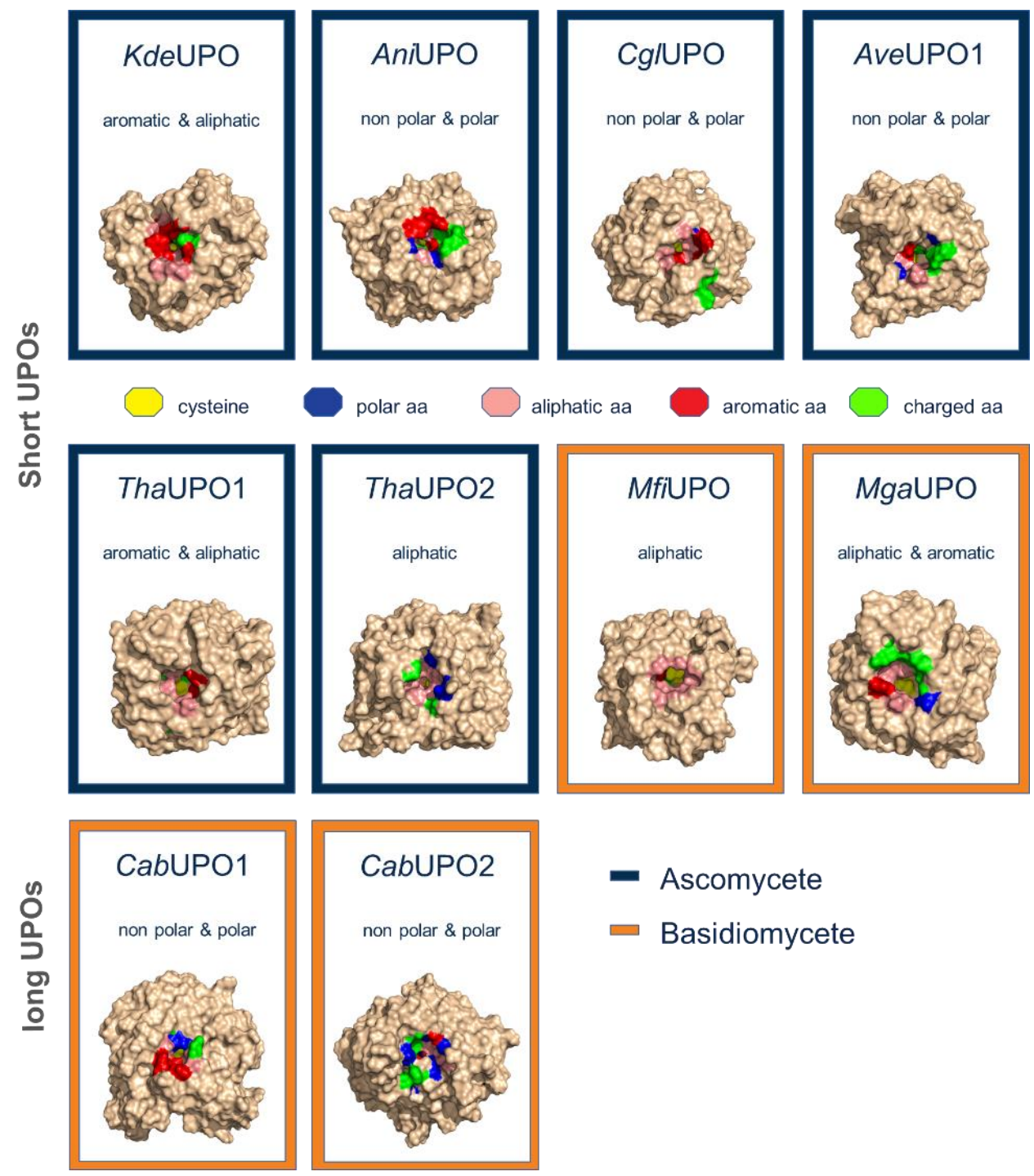

Figure 2. Homology modeled UPO candidates for recombinant expression.

\subsection{Protein Production in P. pastoris}

The best-performing clones identified in the screening, i.e., those that exhibited the highest activities towards ABTS and NBD, were cultivated in a 1-L bioreactor in order to produce sufficient amounts of enzyme for subsequent purification and characterization. Fermentation of $P$. pastoris was carried out according to the widely used multistage fermentation protocol for methanol-induced protein production [20], which consists of a batch glycerol phase for initial biomass production, a glycerol fed-batch phase to accumulate biomass, and the main fed-batch methanol phase, in which only minor biomass accumulation occurs for the actual production of the protein of interest. Protein production, shown by the increase in ABTS activity after methanol induction, was successful for all three constructs identified in the screening (CabUPO 1, CabUPO 2, and rAniUPO), as exemplarily shown in Figure 3 for rCabUPO 2. Activity profiles of all cultivations are given in Figure S2.

Cultivations had to be terminated when the culture volume exceeded the reactors' working volume due to continuous feeding of substrate. Judging from the protein production pattern exhibited, it might well be possible to further increase total protein titers with longer cultivation times. The volumetric ABTS activity that could be produced was in the same order of magnitude for all three proteins and about an order of magnitude lower than that of routine fermentations of recombinant UPO from Cyclocybe aegerita variant PaDaI (rAaeUPO-PaDa-I) [24]. In order to determine whether these differences were the result of 
lower secretion levels or of differences in specific enzyme activities, the cultivation broth was harvested for subsequent protein purification.

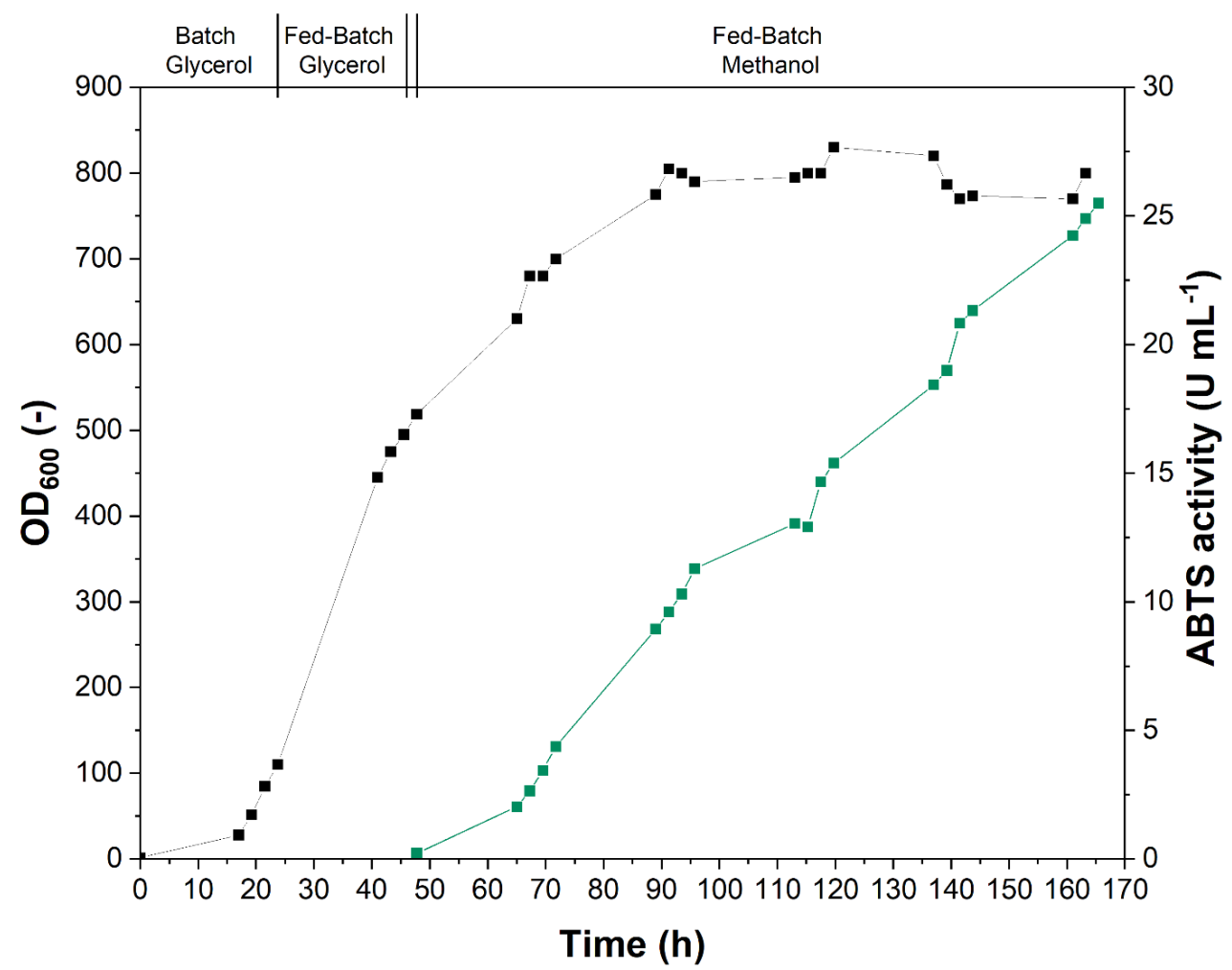

Figure 3. Production of recombinant $\mathrm{rCabUPO} 2$ with P. pastoris $\mathrm{X} 33$ in a 1-L bioreactor. Phases of the glycerol and methanol (fed)-batch process are indicated. A double bar marks the starvation phase preceding the methanol fed-batch. Cultivation was monitored by measurement of $\mathrm{OD}_{600}(\mathbf{\square})$ and enzyme production by determination of the UPO activity towards ABTS ( $\square$ ).

\subsection{Protein Purification}

Culture broth containing rCabUPO1, rCabUPO 2, and rAniUPO was first clarified by centrifugation, then by $0.2 \mu \mathrm{m}$ cross-flow filtration, and was afterwards concentrated via cross-flow ultrafiltration using a $10 \mathrm{kDa}$ cut-off membrane before chromatographic purification by FPLC. The concentrated culture broth was first subjected to hydrophobic interaction chromatography (HIC). rCabUPO 2 eluted in a single peak (Figure 4a), which was significantly narrower than that of $\mathrm{r} A n i \mathrm{UPO}$ (Figure S3c), while rCabUPO 1 eluted in two distinct peaks (Figure S3a). Analysis by SDS-PAGE showed that the two peaks of rCabUPO 1 were of equal molecular weight (Figure S4). Since the first peak represented the majority of the enzyme, all further work was carried out using these fractions. rCabUPO 2 was already purified to near homogeneity after HIC, while rCabUPO 1 showed minor impurities around $35 \mathrm{kDa}$ and $\mathrm{r} A n i \mathrm{UPO}$ did not exhibit a major (distinct) protein band. Size exclusion chromatography (SEC) was carried out after concentration and dialysis of the pooled fractions from the HIC step to further purify the enzymes. While this was not strictly necessary for $\mathrm{rCabUPO} 2$, it was deemed appropriate to treat all enzymes similarly before biochemical characterization. While SEC for rCabUPO 2 (Figure $4 \mathrm{~b}$ ) and rCabUPO 1 (Figure S5a) showed few foreign proteins, as indicated by the overlap in hemespecific absorption and protein absorption, $\mathrm{rAniUPO}$ could be partially separated from contaminating proteins (Figure S5c). Offline photometric measurement of the fractions collected showed that the double peak present in the chromatograms of rCabUPO 2 and rCabUPO 1 was an artifact and did not represent two distinct protein species. Surprisingly, rAniUPO eluted earlier then rCabUPO 1 and $\mathrm{rCabUPO} 2$, although its molecular weight based on the protein sequence was about $10 \mathrm{kDa}$ lower. 


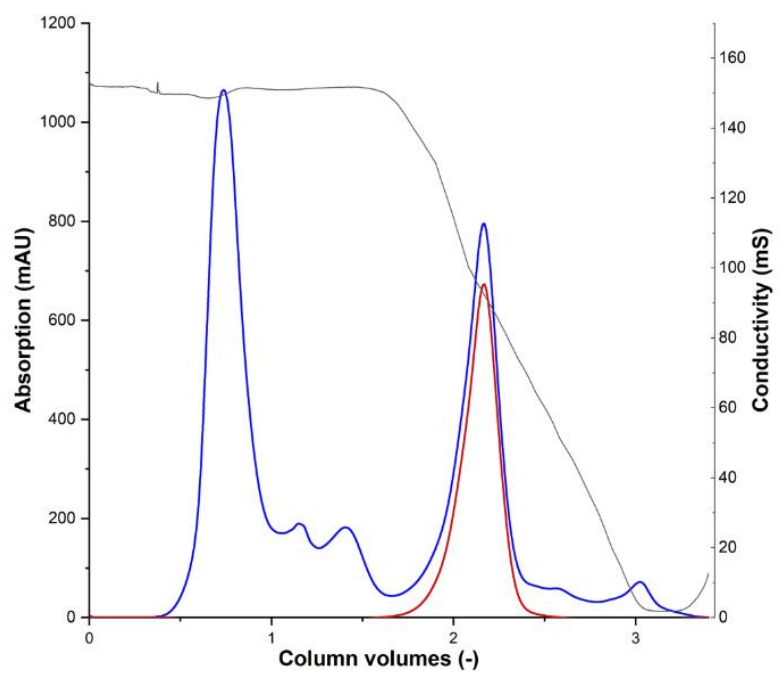

(a) HIC

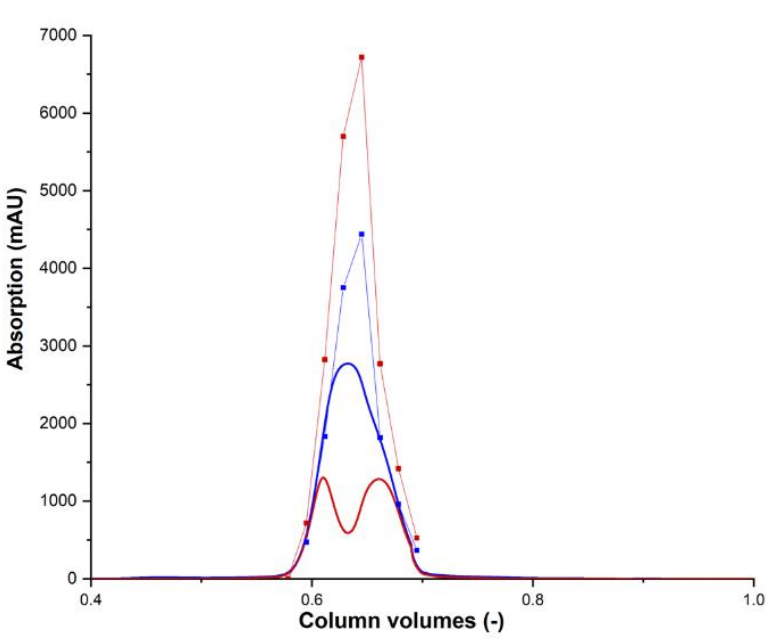

(b) SEC

Figure 4. Purification of rCabUPO 2 by hydrophobic interaction chromatography (HIC) (a) and sizeexclusion chromatography (SEC) (b). Conductivity - , absorption was determined online (280 nm $420 \mathrm{~nm}-$ ) and offline (280 $\mathrm{nm} \mathbf{\square}, 420 \mathrm{~nm}$-).

The purification data are summarized in Table 2. The relatively low increases in specific activity, which were less than two-fold for all enzymes, indicated that the P. pastoris X33 culture broth contained only minor amounts of extracellular host-cell proteins. Based on the specific activity values determined after purification, maximum protein titers of $300 \mathrm{mg} \mathrm{L}^{-1}$ for rCabUPO 1, $275 \mathrm{mg} \mathrm{L}^{-1}$ for rCabUPO 2, and $140 \mathrm{mg} \mathrm{L}^{-1}$ for rAniUPO were calculated for the bioreactor cultivations. These titers are similar to those of routine fermentations of rAaeUPO-PaDa-I with P. pastoris (about $200 \mathrm{mg} \mathrm{L}^{-1}$ in [24]).

Table 2. Purification of rCabUPO 1, rCabUPO 2, and rAniUPO. Supernatant refers to culture broth clarified by centrifugation. Ultrafiltration refers to concentration of supernatant by $0.2-\mu \mathrm{m}$ and $10-\mathrm{kDa}$ ultrafiltration. HIC refers to the pooled fractions of the HIC run after concentration and dialysis against SEC-buffer. SEC refers to pooled fraction of the SEC run after concentration and dialysis against $100 \mathrm{mM}$ potassium phosphate buffer (KPi) pH 7.0. Appl. refers to the volume applied to the next purification step. PF: Purification factor per purification step. Yield: Amount of enzyme activity retained per purification step. Activities were determined using the ABTS assay.

\begin{tabular}{|c|c|c|c|c|c|c|c|c|}
\hline Step & Vol. Act. & Vol. & Act. & Protein & Sp. Act. & Appl. & PF & Yield \\
\hline & $\left(\mathrm{U} \mathrm{mL}^{-1}\right)$ & $(\mathrm{mL})$ & (U) & $\left(g^{-1}\right)$ & $\left(\mathrm{U} \mathrm{mg}^{-1}\right)$ & $\%$ & $(-)$ & $\%$ \\
\hline \multicolumn{9}{|l|}{ rCabUPO 2} \\
\hline Supernatant & $25.3 \pm 1$ & 493 & 12,475 & - & - & 100 & - & - \\
\hline Ultrafiltration & $493.9 \pm 7.8$ & 14.8 & 7309 & 7.88 & 62.64 & 66 & - & 58.6 \\
\hline $\mathrm{HIC}$ & $2821 \pm 226$ & 1.25 & 3526 & 37.7 & 74.84 & 80 & 1.19 & 42.7 \\
\hline SEC & $1218.6 \pm 33.6$ & 2.2 & 2681 & 13.63 & 89.41 & - & 1.19 & 95 \\
\hline \multicolumn{9}{|l|}{ rCabUPO 1} \\
\hline Supernatant & $3.7 \pm 0.1$ & 653 & 2435 & - & - & 100 & - & - \\
\hline Ultrafiltration & $233.2 \pm 1.6$ & 7.6 & 1772 & 23.67 & 9.85 & 100 & - & 72.8 \\
\hline HIC & $899.2 \pm 37.6$ & 1.2 & 1079 & 98.42 & 9.14 & 83 & 0.93 & 44.3 \\
\hline SEC & $356.3 \pm 7.9$ & 2.8 & 998 & 21.99 & 16.2 & - & 1.77 & 110.9 \\
\hline \multicolumn{9}{|l|}{ rAniUPO } \\
\hline Supernatant & $6 \pm 0.3$ & 595 & 3589 & - & - & 100 & - & - \\
\hline Ultrafiltration & $259.6 \pm 5.8$ & 14.8 & 3842 & 6.55 & 39.64 & 60 & - & 107 \\
\hline HIC & $624.9 \pm 7.7$ & 0.98 & 612 & 13.4 & 46.65 & 87 & 1.18 & 28.7 \\
\hline SEC & $172.5 \pm 1.5$ & 1.5 & 259 & 2.34 & 73.57 & - & 1.58 & 48.7 \\
\hline
\end{tabular}




\subsection{Physicochemical Characterization}

Purified, concentrated, and dialyzed proteins were characterized concerning final purity and molecular weight by SDS-PAGE (Figure 5). rCabUPO 1 and rCabUPO 2 bands were in range of predicted weight, while $\mathrm{r} A n i \mathrm{UPO}$ appeared as a non-distinct band at around $55 \mathrm{kDa}$ and $40 \mathrm{kDa}$, which is significantly over the predicted weight of $27.6 \mathrm{kDa}$ for the processed protein (see Table 1). P. pastoris has been reported to over-glycosylate foreign proteins, which was shown for various enzymes including a UPO [24]. Since high-mannose $\mathrm{N}$-glycosylation is most prevalent in P. pastoris [25], proteins were deglycosylated using PNGase F in order to remove possible oligosaccharides. Deglycosylation led to a minor shift in molecular weight for rCabUPO 1 and rCabUPO 2 to slightly below and above $40 \mathrm{kDa}$, respectively. This is in good agreement with their predicted molecular weights of $38.3 \mathrm{kDa}$ and $39.3 \mathrm{kDa}$ (Table 1). Both major and minor bands of $\mathrm{r} A n i \mathrm{UPO}$ shifted to a single band above $25 \mathrm{kDa}$ after deglycosylation, which matches the predicted molecular weight of $27.6 \mathrm{kDa}$. This led us conclude that $\mathrm{r} A$ niUPO becomes highly over-glycosylated when expressed in P. pastoris with an estimated glycosylation degree of up to $50 \%$. This in turn results in a high degree of glycosylation-derived heterogeneity, as indicated by the presence of the hyper-glycosylated major and the less glycosylated minor bands. As such, differently glycosylated protein fractions were also observed for wild-type AaeUPO $[2,26]$. The results for all three rUPOs are in agreement with predicted N-glycosylation sites, and thereby the sequence of $\mathrm{r} A n i \mathrm{UPO}$ having six potential $\mathrm{N}$-glycosylation sites, whereas both sequences of Candolleomyces rUPOs showed only two to three sites.

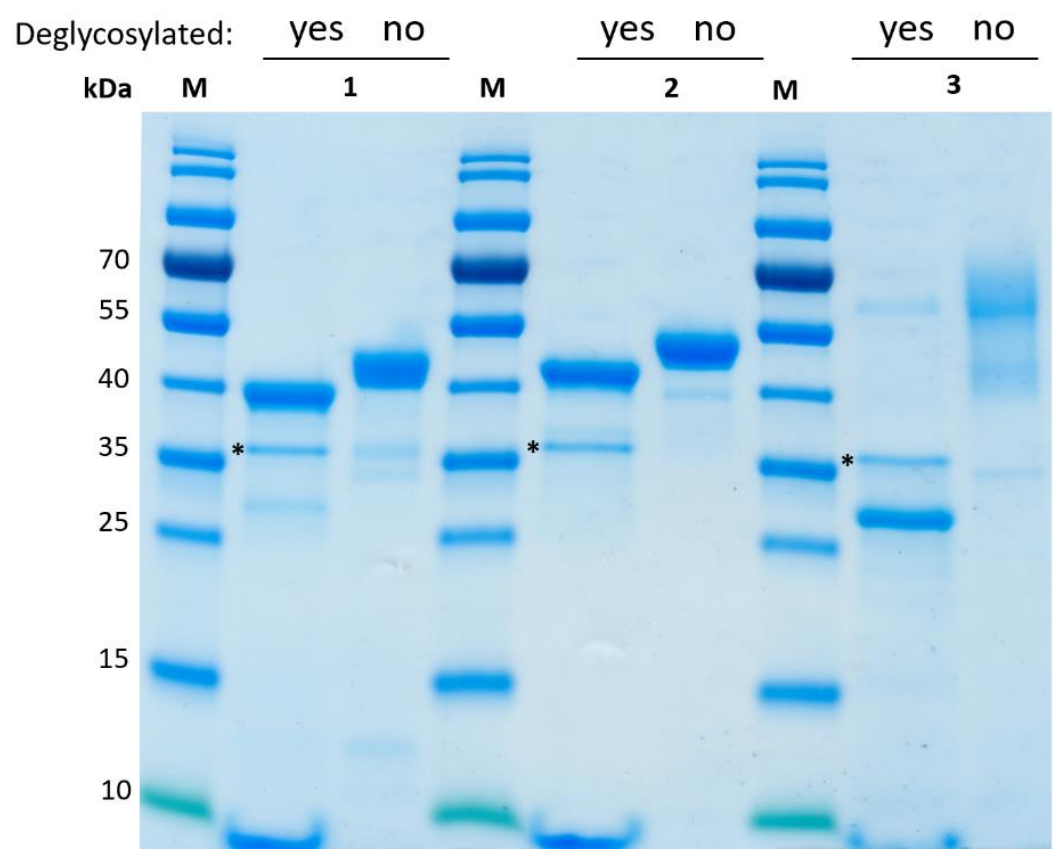

Figure 5. Analysis of protein purity and glycosylation content of purified proteins before and after N-deglycosylation with PNGase F. Lanes: M PageRuler Prestained (ThermoFisher), 1 rCabUPO 1, 2 rCabUPO 2, 3 rAniUPO. The band representing PNGase F (35.9 kDa) is indicated $\left(^{*}\right)$.

Spectra of the purified enzymes exhibited the heme-thiolate typical Soret region around $420 \mathrm{~nm}$, as well as the charge transfer bands at about $530 \mathrm{~nm}$ and $570 \mathrm{~nm}$ (Figure S6). The Reinheitszahl (RZ, Absorption soret $_{\text {Absorption }} 280 \mathrm{~nm}$ ), which is often used as an indicator for the purity of heme-containing enzymes, was well above two for rCabUPO 1 , in accordance with the high degree of purity determined by SDS-PAGE. While rCabUPO 2 was similarly pure by SDS-PAGE, its RZ was notably lower, which could have been the result of partial loss or lack of heme-incorporation [27]. While electrophoretically almost pure as well, the even lower RZ of rAniUPO might be caused (at least to some extent) by the 
high glycosylation degree. Characteristic features of the purified proteins are summarized in Table 3.

Table 3. Size and spectroscopic characteristics of rCabUPO 1, rCabUPO 2, and rAniUPO. Molecular mass of glycosylated and deglycosylated UPO proteins were calculated from Figure 5. Molecular weights of the mature proteins, i.e., excluding the $\mathrm{N}$-terminal secretion signal, were predicted using SignalP 5.0 [28].

\begin{tabular}{ccccc}
\hline Feature & & rCabUPO 1 & rCabUPO 2 & rAniUPO \\
\hline $\mathrm{M}_{\mathrm{W}}$ glycosylated & $(\mathrm{kDa})$ & 45 & 50 & 60 \\
$\mathrm{M}_{\mathrm{W}}$ deglycosylated & $(\mathrm{kDa})$ & 39 & 42 & 28 \\
$\mathrm{M}_{\mathrm{W}}$ predicted & $(\mathrm{kDa})$ & 38.8 & 39.3 & 27.6 \\
Soret region & $(\mathrm{nm})$ & 417 & 419 & 420 \\
Charge transfer band 1 & $(\mathrm{nm})$ & 570 & 572 & 569 \\
Charge transfer band 2 & $(\mathrm{nm})$ & 535 & 540 & 541 \\
Reinheitszahl & $\left(\mathrm{A}_{\text {Soret }} / \mathrm{A}_{280}\right)$ & 2.5 & 1.5 & 1.2 \\
\hline
\end{tabular}

\subsection{Comparison of Enzyme Activities}

Purified rCabUPO 1, rCabUPO 2, and $\mathrm{r} A n i \mathrm{UPO}$ were compared regarding their specific activities and $\mathrm{pH}$-optima for typical UPO substrates. Storage of the enzymes at $4{ }^{\circ} \mathrm{C}$ after purification for several days led to partial inactivation, most notably in the form of irreversible protein denaturation (which became visible by precipitation). For this reason, pH-optima and activities of all samples were normalized and 'absolute' specific activities are not given. $\mathrm{pH}-\mathrm{Optima}$ were determined with the substrates ABTS, NBD, and VA (veratryl alcohol; Figure 6). The pH-optima for ABTS oxidation varied significantly for rCabUPO 1 and rCabUPO 2, which is noteworthy, since both enzymes originate from the same organism. Similar behavior was observed for the evolved CabUPOs [9]. Activities of $\mathrm{r}$ AniUPO were generally more pronounced at lower $\mathrm{pH}$ and considerable differences in the relative activities towards the substrates investigated were noticed (Figure 7). Most notable were the differences in the VA-oxidizing activity, which was quite high for rCabUPO 2, whereas AniUPO showed hardly any activity towards VA. A deeper biochemical characterization of the new UPOs is out of the scope of this paper, but will be performed in the future.

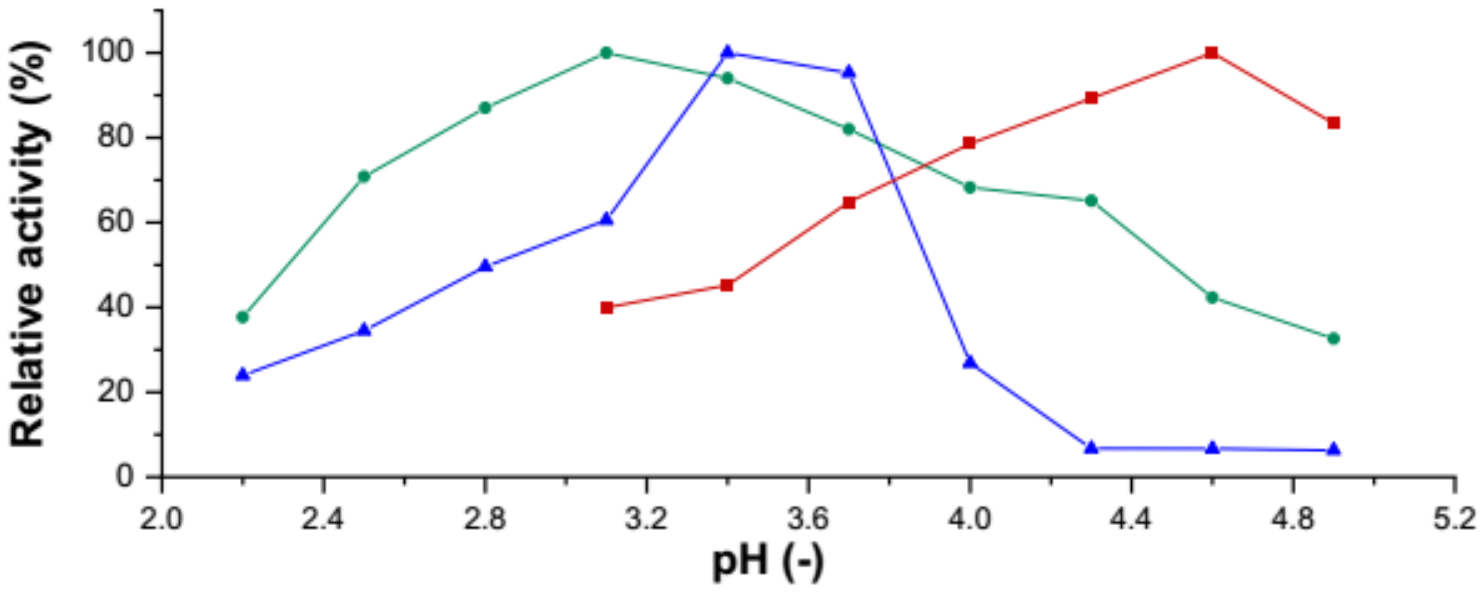

(a)

Figure 6. Cont. 


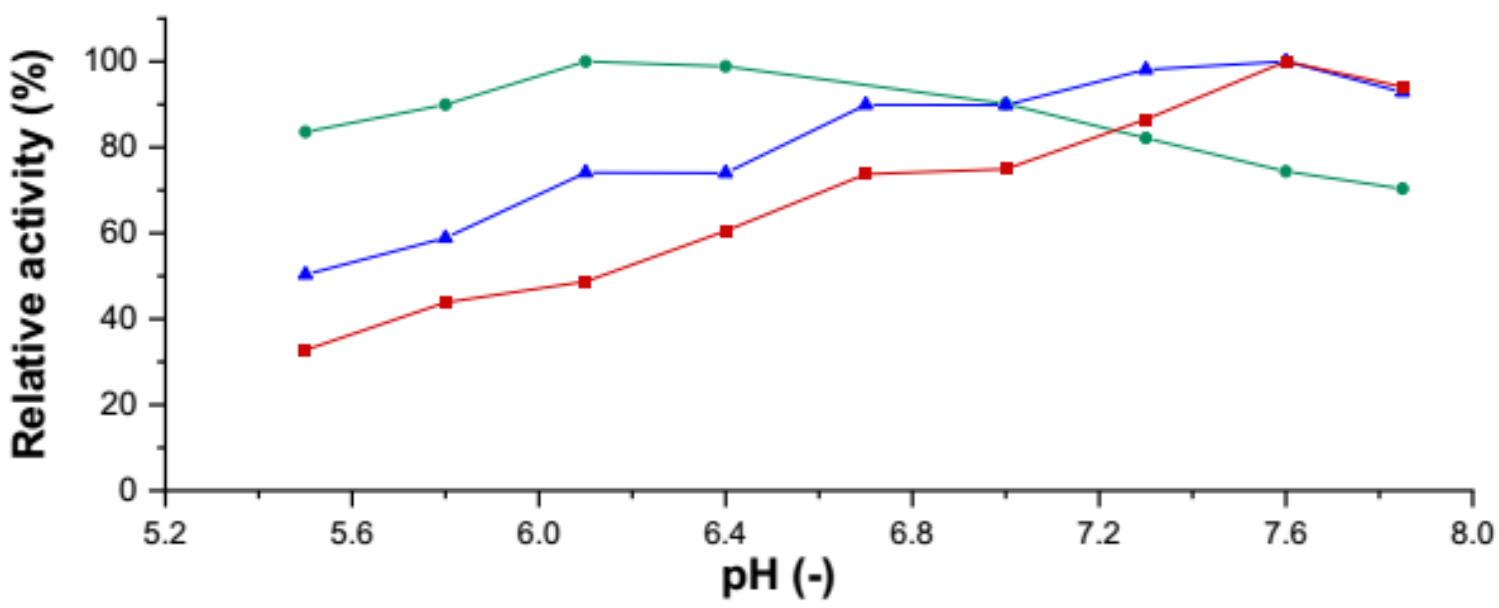

(b)

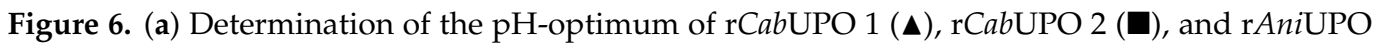
$(\bullet)$ using ABTS as a substrate. An activity of $100 \%$ corresponds to the highest activity measured for each individual enzyme. (b) Determination of the pH-optimum of rCabUPO 1 ( $\mathbf{\Delta}), \mathrm{rCabUPO} 2$ ( $\mathbf{\square})$, and $\mathrm{r} A n i \mathrm{UPO}(\bullet)$ using NBD as a substrate. An activity of $100 \%$ corresponds to the highest activity measured for each individual enzyme.

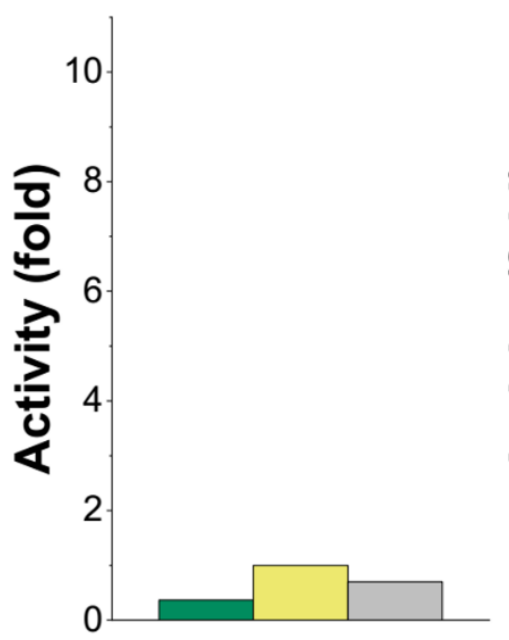

(a) rCabUPO1

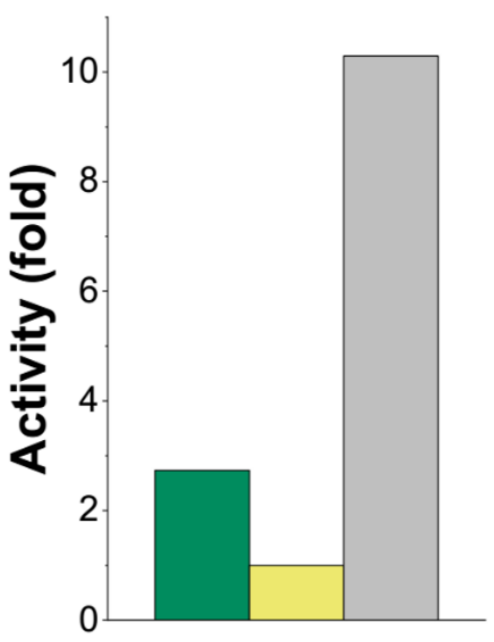

(b) rCabUPO2

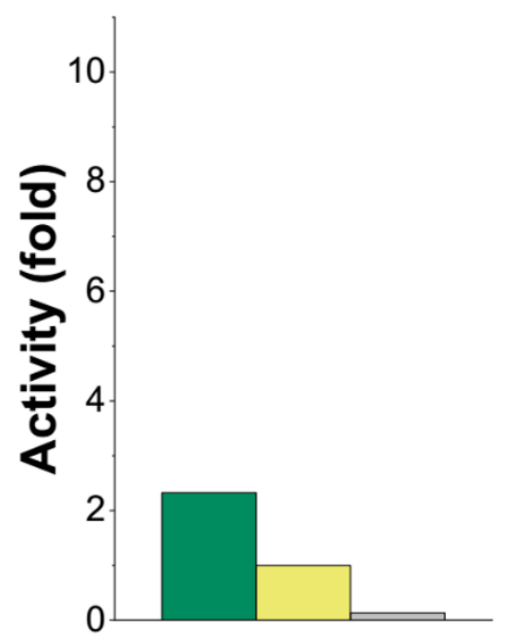

(c) rAniUPO

Figure 7. Relative activities of purified rUPO proteins towards ABTS ( $\square)$, NBD ( ), and VA ( () . Specific activities were normalized by dividing the specific activity of a respective substrate at $\mathrm{pH}$-optimum by the specific NBD activity at $\mathrm{pH}$-optimum. NBD was chosen for normalization as all enzymes exhibited similar activities $\left(10-30 \mathrm{U}_{\mathrm{NBD}} \mathrm{mg}^{-1}\right)$ towards this substrate $(\mathrm{n}=1)$.

None of the here-studied UPO enzymes currently have an experimentally resolved tertiary structure (e.g., by x-ray diffraction, solution NMR, or electron microscopy). Their respective 3D structures were instead simulated by using the computational C-I-TASSER pipeline (version 1.0; [12]) for contact-guided protein structure prediction. Special focus was given to the visualization of the substrate access channels (Figure 8) of rAniUPO and its structurally closest fit of an experimentally resolved and published UPO crystal structure (that of Marasmius rotula UPO/ MroUPO, PDB accession: 5FUK, chain A). The 3D models of the evolved rCabUPOs have recently been published [12]. The top C-I-TASSER-predicted model of rAniUPO had a C-score (confidence score) of 1.98 (on a scale of -5 to +2 ; higher is better) and an estimated TM-score (estimated correctness of global topology) of $0.99 \pm 0.04$. 

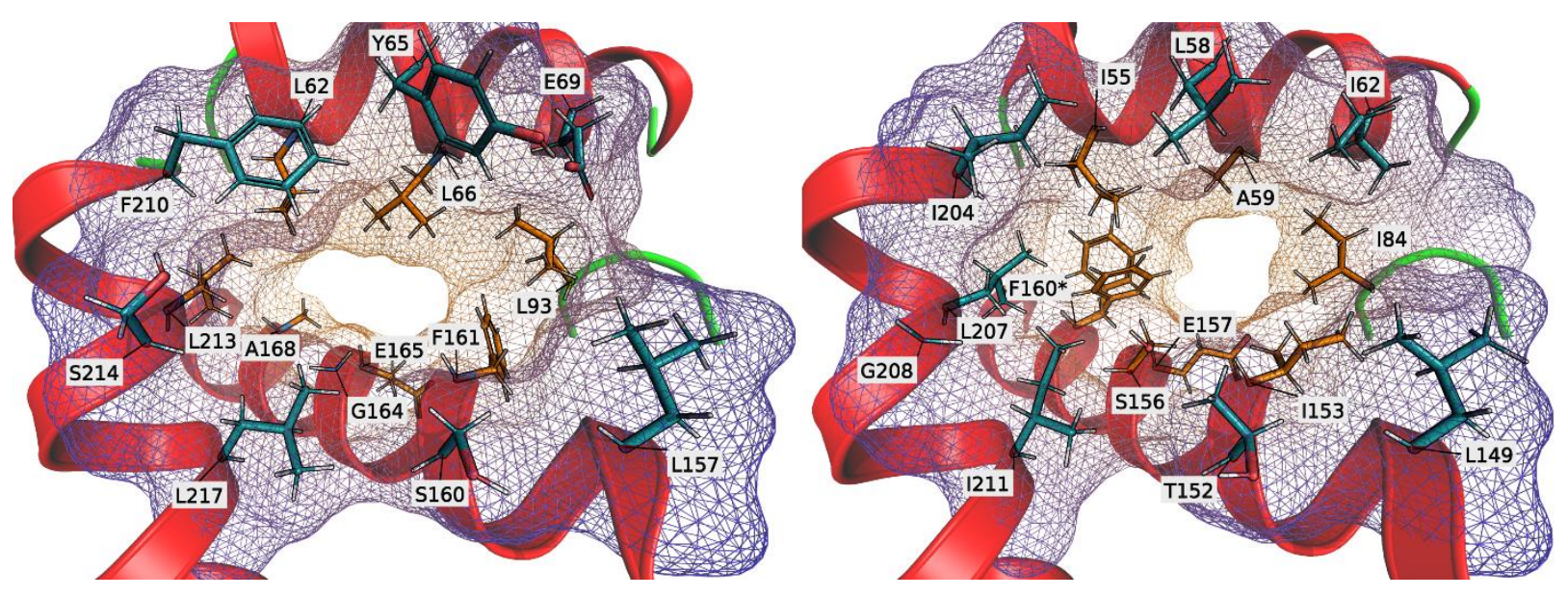

Figure 8. Amino acids defining the substrate access channel of $\mathrm{r} A n i \mathrm{UPO}$ (left) and MroUPO (right) in a top-down view from the protein surface to the channel bottleneck. Main-chain secondary structures are shown as cartoon helices (red) or loops (green). Side-chains (depicted as sticks) are labeled using the IUPAC standard one-letter amino acid code. The field-of-view was reduced to $60^{\circ}$ (aids depthperception and reduces visual cluttering). The solvent excluded surface (SES) of the channel-lining amino acids is depicted as a colored mesh (ignoring all other amino acids). The meshes are colored from blue (bottleneck distal) to orange (bottleneck proximal) and are colored in approximation as the amino-acid side-chains that either form the channel-bottleneck (in orange) or rather the outer channel perimeter (in blue). (*) F160 in the resolved structure for MroUPO (5FUK) has two rotamer-solutions (while 5FUJ has two rotamer-solutions for I55 but not F160; not shown).

Comparing the simulated $\mathrm{r} A n i \mathrm{UPO}$ model and the resolved MroUPO in a structural alignment yielded a TM-score of 0.93 , indicating a high global structural similarity between both proteins (based on weighted average distance of all residue pairs between the alignments). In Figure 7, this is reflected in an almost identical relative protein backbone positioning around the substrate access channel. This in turn points to individual differences in channel side-chain residues between both proteins to largely define their respective channel topology in detail (and the specific substrate spectra). MroUPO's channel-bottleneck was squarish, while rAniUPO's bottleneck was oblong. Taking Figure 8 as reference for orientation, then MroUPO's left and right bottleneck flanks were mostly defined by sidechain residues F160 and I84 and the top flank by A59. The bottom flank was defined mainly by the peptide backbone between E157 and S156. rAniUPO's channel-bottleneck was squished oblong by a much bulkier L66 that protruded into the channel from the top (A59 in MroUPO), while the bottleneck was at the same time offset to the left due to F161 (I153 in MroUPO). This diminished the influence of L93 in rAniUPO's bottleneck topology (I84 in MroUPO). The bottom flank of rAniUPO's bottleneck was mostly defined by the peptide backbone of E165 and G164, similar to MroUPO. Additionally, the left flank of rAniUPO's bottleneck was opened up relatively to that of MroUPO (substituting F160 in MroUPO by A168 in rAniUPO). This in turn allowed rAniUPO's L62 to participate in the topology of the bottleneck flank (whereas I55 hardly did in MroUPO).

To combine structural insights with measured enzyme activity, we ran docking simulations to fit VA into rAniUPO's and as comparison MroUPO's substrate access channel (Figure S7). While the simulation makes it feasible that VA fits into rAniUPO's substrate access channel, the need to present its hydroxyl-group to the heme combined with the need to accommodate its methoxy-groups makes it an awkward fit, which in turn could explain the low oxidation activity of rAniUPO for VA compared with other UPOs.

\section{Conclusions}

Out of a selection of ten putative UPO genes, three enzymes exhibited activities towards UPO-typical screening substrates. These enzymes were successfully produced 
in P. pastoris in a multi-stage, high-cell-density cultivation without using an expression strategy involving first trials in E. coli or S. cerevisiae. Protein titers of $140-300 \mathrm{mg} \mathrm{L}^{-1}$ were achieved for rCabUPO 1, rCabUPO 2, and rAniUPO, demonstrating that directed evolution is not essential for the production of this enzyme type in yeast (this result is in good agreement with [8]). Nevertheless, it is out of question that any kind of genetic engineering will have to take place in S. cerevisiae. Though two of the three UPOs produced originated from the same organism, all enzymes exhibited markedly different activities towards the three test substrates along with varying $\mathrm{pH}$ profiles. Obviously, a more thorough investigation of their activities, especially with respect to industrially relevant substrates (e.g., pharmaceuticals), will be required in the future. Nonetheless, the results presented here increase the toolbox of UPOs available for genetic engineering and heterologous expression - a general requirement for the industrial application of this enzyme type. The described expression of new UPOs, the (evolutionary) optimization of the enzymes $[6,9,24,29-31]$, as well as process-engineering approaches [32-37] will certainly make UPOs a key player in technical oxy-functionalization in the future.

Supplementary Materials: The following supporting information can be downloaded at: https:// www.mdpi.com/article/10.3390/antiox11020223/s1 Figure S1: Screening of supernatant of P. pastoris clones transformed with UPO expression plasmids; Figure S2: Production of recombinant UPOs with P. pastoris X33 in a bioreactor; Figure S3: Purification of UPOs by hydrophobic interaction chromatography (HIC); Figure S4: SDS-PAGE analysis of pooled fractions after HIC purification, Figure S5: Purification of UPOs by size exclusion chromatography; Figure S6: Absorption spectra of purified proteins; Figure S7: VA-docking simulation results for AniUPO and MroUPO; Table S1: Primers used for the construction of pPpB1-based UPO expression plasmids; DNA-Sequences of UPO genes.

Author Contributions: Conceptualization, S.B., H.K., M.H., D.H.; methodology, S.B., H.K., R.H., R.U. (René Ullrich), C.L.; validation, S.B., H.K., R.U. (René Ullrich), R.U. (Robert Herzog); investigation, S.B., H.K., J.H., R.U. (René Ullrich), C.L.; writing—original draft preparation, S.B., H.K., R.H; supervision, R.U. (Robert Herzog), M.H., D.H.; project administration, M.H., D.H.; funding acquisition, M.H., D.H. All authors have read and agreed to the published version of the manuscript.

Funding: This research was funded by AiF German Federation of Industrial Research Associations “Otto von Guericke" e. V. (Project no. 19636 N) and the DFG (HO 5667/10-1).

Institutional Review Board Statement: Not applicable.

Informed Consent Statement: Not applicable.

Data Availability Statement: Data is contained within the article or supplementary material.

Acknowledgments: S.B.: K.K., M.H., D.H. gratefully acknowledges funding by the AiF German Federation of Industrial Research Associations "Otto von Guericke" e. V. (Project no. 19636 N), D.H. would like to express his acknowledgment of the financial support provided by the Strategic Research Fund of THM and the DFG (HO 5667/10-1).

Conflicts of Interest: The authors declare no conflict of interest.

\section{References}

1. Hofrichter, M.; Kellner, H.; Herzog, R.; Karich, A.; Liers, C.; Scheibner, K.; Kimani, V.W.; Ullrich, R. Fungal Peroxygenases: A Phylogenetically Old Superfamily of Heme Enzymes with Promiscuity for Oxygen Transfer Reactions. In Grand Challenges in Fungal Biotechnology; Nevalainen, H., Ed.; Springer International Publishing: Cham, Switzerland, 2020; pp. 369-403. [CrossRef]

2. Hofrichter, M.; Kellner, H.; Pecyna, M.J.; Ullrich, R. Fungal unspecific peroxygenases: Heme-thiolate proteins that combine peroxidase and cytochrome p450 properties. Adv. Exp. Med. Biol. 2015, 851, 341-368. [CrossRef] [PubMed]

3. Burek, B.O.; Bormann, S.; Hollmann, F.; Bloh, J.Z.; Holtmann, D. Hydrogen peroxide driven biocatalysis. Green Chem. 2019, 21, 3232-3249. [CrossRef]

4. Martínez, A.T.; Ruiz-Dueñas, F.J.; Camarero, S.; Serrano, A.; Linde, D.; Lund, H.; Vind, J.; Tovborg, M.; Herold-Majumdar, O.M.; Hofrichter, M.; et al. Oxidoreductases on their way to industrial biotransformations. Biotechnol. Adv. 2017, 35, 815-831. [CrossRef] [PubMed] 
5. Hobisch, M.; Holtmann, D.; Gomez de Santos, P.; Alcalde, M.; Hollmann, F.; Kara, S. Recent developments in the use of peroxygenases-Exploring their high potential in selective oxyfunctionalisations. Biotechnol. Adv. 2020, 107615. [CrossRef]

6. Molina-Espeja, P.; Garcia-Ruiz, E.; Gonzalez-Perez, D.; Ullrich, R.; Hofrichter, M.; Alcalde, M. Directed Evolution of Unspecific Peroxygenase from Agrocybe aegerita. Appl. Environ. Microbiol. 2014, 80, 3496-3507. [CrossRef]

7. $\quad$ Linde, D.; Olmedo, A.; González-Benjumea, A.; Estévez, M.; Renau-Mínguez, C.; Carro, J.; Fernández-Fueyo, E.; Gutiérrez, A.; Martínez, A.T. Two New Unspecific Peroxygenases from Heterologous Expression of Fungal Genes in Escherichia coli. Appl. Environ. Microbiol. 2020, 86, e02899-19. [CrossRef]

8. Rotilio, L.; Swoboda, A.; Ebner, K.; Rinnofner, C.; Glieder, A.; Kroutil, W.; Mattevi, A. Structural and Biochemical Studies Enlighten the Unspecific Peroxygenase from Hypoxylon sp. EC38 as an Efficient Oxidative Biocatalyst. ACS Catal. 2021, 11, 11511-11525. [CrossRef]

9. Santos, P.G.d.; Hoang, M.D.; Kiebist, J.; Kellner, H.; Ullrich, R.; Scheibner, K.; Hofrichter, M.; Liers, C.; Alcalde, M.; Master, E.R Functional Expression of Two Unusual Acidic Peroxygenases from Candolleomyces aberdarensis in Yeasts by Adopting Evolved Secretion Mutations. Appl. Environ. Microbiol. 2021, 87, e00878-21. [CrossRef]

10. Babot, E.D.; del Río, J.C.; Kalum, L.; Martínez, A.T.; Gutiérrez, A. Oxyfunctionalization of aliphatic compounds by a recombinant peroxygenase from Coprinopsis cinerea. Biotechnol. Bioeng. 2013, 110, 2323-2332. [CrossRef]

11. Roy, A.; Kucukural, A.; Zhang, Y. I-TASSER: A unified platform for automated protein structure and function prediction. Nat. Protoc. 2010, 5, 725-738. [CrossRef]

12. Zheng, W.; Zhang, C.; Li, Y.; Pearce, R.; Bell, E.W.; Zhang, Y. Folding non-homologous proteins by coupling deep-learning contact maps with I-TASSER assembly simulations. Cell Rep. Methods 2021, 1, 100014. [CrossRef] [PubMed]

13. Gaudreault, F.; Morency, L.-P.; Najmanovich, R.J. NRGsuite: A PyMOL plugin to perform docking simulations in real time using FlexAID. Bioinformatics 2015, 31, 3856-3858. [CrossRef] [PubMed]

14. Guindon, S.; Dufayard, J.-F.; Lefort, V.; Anisimova, M.; Hordijk, W.; Gascuel, O. New Algorithms and Methods to Estimate Maximum-Likelihood Phylogenies: Assessing the Performance of PhyML 3.0. Syst. Biol. 2010, 59, 307-321. [CrossRef] [PubMed]

15. Kearse, M.; Moir, R.; Wilson, A.; Stones-Havas, S.; Cheung, M.; Sturrock, S.; Buxton, S.; Cooper, A.; Markowitz, S.; Duran, C.; et al Geneious Basic: An integrated and extendable desktop software platform for the organization and analysis of sequence data. Bioinformatics 2012, 28, 1647-1649. [CrossRef]

16. Nielsen, H.; Engelbrecht, J.; Brunak, S.; von Heijne, G. Identification of prokaryotic and eukaryotic signal peptides and prediction of their cleavage sites. Protein Eng. Des. Sel. 1997, 10, 1-6. [CrossRef]

17. Gibson, D.G.; Young, L.; Chuang, R.-Y.; Venter, J.C.; Hutchison, C.A.; Smith, H.O. Enzymatic assembly of DNA molecules up to several hundred kilobases. Nat. Methods 2009, 6, 343-345. [CrossRef]

18. Weis, R.; Luiten, R.; Skranc, W.; Schwab, H.; Wubbolts, M.; Glieder, A. Reliable high-throughput screening with Pichia pastoris by limiting yeast cell death phenomena. FEMS Yeast Res. 2004, 5, 179-189. [CrossRef]

19. Poraj-Kobielska, M.; Kinne, M.; Ullrich, R.; Scheibner, K.; Hofrichter, M. A spectrophotometric assay for the detection of fungal peroxygenases. Anal. Biochem. 2012, 421, 327-329. [CrossRef]

20. Cino, J. High-yield protein production from Pichia pastoris yeast: A protocol for benchtop fermentation. Am. Biotechnol. Lab. $1999,17,10-12$.

21. Kiebist, J.; Schmidtke, K.-U.; Zimmermann, J.; Kellner, H.; Jehmlich, N.; Ullrich, R.; Zänder, D.; Hofrichter, M.; Scheibner, K. A Peroxygenase from Chaetomium globosum Catalyzes the Selective Oxygenation of Testosterone. ChemBioChem 2017, 18, 563-569. [CrossRef]

22. Dyballa, N.; Metzger, S. Fast and sensitive colloidal coomassie G-250 staining for proteins in polyacrylamide gels. J. Vis. Exp. 2009, 30, e1431. [CrossRef] [PubMed]

23. Abad, S.; Nahalka, J.; Bergler, G.; Arnold, S.A.; Speight, R.; Fotheringham, I.; Nidetzky, B.; Glieder, A. Stepwise engineering of a Pichia pastoris D-amino acid oxidase whole cell catalyst. Microb. Cell Fact. 2010, 9, 24. [CrossRef] [PubMed]

24. Molina-Espeja, P.; Ma, S.; Mate, D.M.; Ludwig, R.; Alcalde, M. Tandem-yeast expression system for engineering and producing unspecific peroxygenase. Enzym. Microb. Technol. 2015, 73-74, 29-33. [CrossRef] [PubMed]

25. Laukens, B.; De Wachter, C.; Callewaert, N. Engineering the Pichia pastoris N-Glycosylation Pathway Using the GlycoSwitch Technology. Methods Mol. Biol. 2015, 1321, 103-122. [CrossRef] [PubMed]

26. Ullrich, R.; Liers, C.; Schimpke, S.; Hofrichter, M. Purification of homogeneous forms of fungal peroxygenase. Biotechnol. J. 2009, 4, 1619-1626. [CrossRef]

27. Zong, Q.; Osmulski, P.A.; Hager, L.P. High-Pressure-Assisted Reconstitution of Recombinant Chloroperoxidase. Biochemistry 1995, 34, 12420-12425. [CrossRef]

28. Almagro Armenteros, J.J.; Tsirigos, K.D.; Sønderby, C.K.; Petersen, T.N.; Winther, O.; Brunak, S.; von Heijne, G.; Nielsen, H SignalP 5.0 improves signal peptide predictions using deep neural networks. Nat. Biotechnol. 2019, 37, 420-423. [CrossRef]

29. Martin-Diaz, J.; Paret, C.; García-Ruiz, E.; Molina-Espeja, P.; Alcalde, M. Shuffling the Neutral Drift of Unspecific Peroxygenase in Saccharomyces cerevisiae. Appl. Environ. Microbiol. 2018, 84, e00808-18. [CrossRef]

30. Martin-Diaz, J.; Molina-Espeja, P.; Hofrichter, M.; Hollmann, F.; Alcalde, M. Directed evolution of unspecific peroxygenase in organic solvents. Biotechnol. Bioeng. 2021. [CrossRef] 
31. Knorrscheidt, A.; Püllmann, P.; Schell, E.; Homann, D.; Freier, E.; Weissenborn, M.J. Identification of Novel Unspecific Peroxygenase Chimeras and Unusual YfeX Axial Heme Ligand by a Versatile High-Throughput GC-MS Approach. ChemCatChem 2020, 12, 4788-4795. [CrossRef]

32. Carballares, D.; Morellon-Sterling, R.; Xu, X.; Hollmann, F.; Fernandez-Lafuente, R. Immobilization of the Peroxygenase from Agrocybe aegerita. The Effect of the Immobilization $\mathrm{pH}$ on the Features of an Ionically Exchanged Dimeric Peroxygenase. Catalysts 2021, 11, 560. [CrossRef]

33. Rauch, M.C.R.; Tieves, F.; Paul, C.E.; Arends, I.W.C.E.; Alcalde, M.; Hollmann, F. Peroxygenase-Catalysed Epoxidation of Styrene Derivatives in Neat Reaction Media. ChemCatChem 2019, 11, 4519-4523. [CrossRef] [PubMed]

34. Bormann, S.; van Schie, M.M.C.H.; De Almeida, T.P.; Zhang, W.; Stöckl, M.; Ulber, R.; Hollmann, F.; Holtmann, D. $\mathrm{H}_{2} \mathrm{O}_{2}$ Production at Low Overpotentials for Electroenzymatic Halogenation Reactions. ChemSusChem 2019, 12, 4759-4763. [CrossRef] [PubMed]

35. Bormann, S.; Burek, B.O.; Ulber, R.; Holtmann, D. Immobilization of unspecific peroxygenase expressed in Pichia pastoris by metal affinity binding. Mol. Catal. 2020, 492, 110999. [CrossRef]

36. Bormann, S.; Hertweck, D.; Schneider, S.; Bloh, J.Z.; Ulber, R.; Spiess, A.C.; Holtmann, D. Modeling and simulation-based design of electroenzymatic batch processes catalyzed by unspecific peroxygenase from A. aegerita. Biotechnol. Bioeng. 2021, 118, 7-16. [CrossRef]

37. Burek, B.O.; de Boer, S.R.; Tieves, F.; Zhang, W.; van Schie, M.; Bormann, S.; Alcalde, M.; Holtmann, D.; Hollmann, F.; Bahnemann, D.W.; et al. Photoenzymatic Hydroxylation of Ethylbenzene Catalyzed by Unspecific Peroxygenase: Origin of Enzyme Inactivation and the Impact of Light Intensity and Temperature. ChemCatChem 2019, 11, 3093-3100. [CrossRef] 